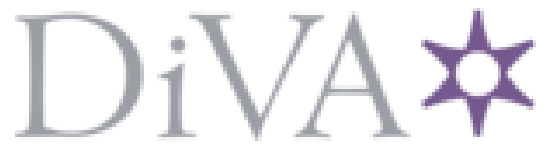

http://www.diva-portal.org

\title{
Postprint
}

This is the accepted version of a paper published in Holzforschung. This paper has been peerreviewed but does not include the final publisher proof-corrections or journal pagination.

Citation for the original published paper (version of record):

Brännvall, E., Bäckström, M. (2016)

Improved impregnation efficiency and pulp yield of softwood kraft pulp by high effective alkali charge in the impregnation stage

Holzforschung, 70(11): 1031-1037

https://doi.org/10.1515/hf-2016-0020

Access to the published version may require subscription.

N.B. When citing this work, cite the original published paper.

Permanent link to this version:

http://urn.kb.se/resolve?urn=urn:nbn:se:ri:diva-26206 


\section{Elisabet Brännvall* and Marie Bäckström \\ Improved impregnation efficiency and pulp yield of softwood kraft pulp by high effective alkali charge in the impregnation stage}

DOI 10.1515/hf-2016-0020

Received January 27, 2016; accepted May 4, 2016; previously published online $x x$

\begin{abstract}
A pulp yield increase up to $2 \%$ can be achieved by impregnation with a liquor containing $2 \mathrm{M}$ effective alkali (EA) concentration instead of $1 \mathrm{M}$. The yield increase is due to higher cellulose and glucomannan contents in the pulp, which can be rationalized by less yield loss by peeling, as impregnation is more effective at an elevated EA level. A rapid loading of chips with alkali can be realized due to a high diffusion rate. When the temperature becomes higher in the cooking stage, enough alkali is available for delignification reactions without the risk of alkali depletion in the chip core, so that the delignification is more homogeneous.
\end{abstract}

Keywords: carbohydrate composition, homogeneous delignification, impregnation, kraft pulping, pulp yield, softwood pulping

\section{Introduction}

The pulp yield in softwood kraft pulping for bleachable paper grades is approx. $47 \%$, a level that has remained unchanged for many years (Janson and Teder 1986; Gullichsen 1999; Kangas et al. 2014). There is a theoretical potential for higher yields in view of the fact that softwoods contain around $70 \%$ polysaccharides. However, the delignification is not selective; thus, lignin and polysaccharides are dissolved partly simultaneously. In the beginning of pulping, the alkali concentration decreases sharply because the acetyl groups are split off and the resulting acetic acid is neutralized by alkali. This leads

\footnotetext{
*Corresponding author: Elisabet Brännvall, Fiber and Polymer Technology, Royal Institute of Technology, KTH, SE-100 44 Stockholm Sweden/Innventia AB, Box 5604, SE-114 86 Stockholm, Sweden, e-mail: bettan@kth.se; elisabet.brannvall@innventia.com. http://orcid.org/0000-0002-8992-3623

Marie Bäckström: Innventia AB, Box 5604, SE-114 86 Stockholm, Sweden
}

to concentration gradients, with high alkali concentrations in the interface between the liquor and the chip, which decreases sharply toward the chip's internal part (Zanuttini and Marzocchi 2000; Zanuttini et al. 2005). If the temperature is elevated before the chips are homogeneously impregnated, the delignification of fibers at the chip surface begins, while the chip center still lacks active cooking chemicals (Malkov et al. 2003). The resulting higher residual lignin content in chip cores leads to formation of shives, which have to be eliminated and this also contributes to yield losses. In parallel, the selectivity of delignification at the surfaces is deteriorated, where more polysaccharides are dissolved than in the chip center.

Improving impregnation homogeneity would increase the pulp yield and decrease the shives content. Thinner chips can also contribute to this goal via homogeneous impregnation (Hartler and Onisko 1962; Jimenez et al. 1990; Gullichsen et al. 1992; Egas et al. 2002; Malkov et al. 2003). However, this approach has limitations not only because of the higher energy demand for chip production but also for higher amounts of pin chips and fines, which result in yield losses. Another way to improve impregnation is by introducing cracks into the chips, which is a measurement equivalent to chip thickness reduction (Määttänen and Tikka 2008).

Longer impregnation time also improves impregnation (Jimenez et al. 1990). This concept realized in combination with low temperature cooking and with a higher liquor-to-wood ratio (L/W), actually results in a more homogeneous delignification (Karlström 2009; Wedin et al. 2010). However, implementing this technology requires either a larger impregnation vessel or a lower production rate. The challenge is to improve impregnation by increasing the diffusion rate of active chemicals into the chips without additional investments and affecting the production rate.

The impregnation should be fast and selective, with conditions favoring diffusion and deacetylation in competition with the undesired peeling and alkaline hydrolysis. Higher temperature increases the ion mobility but, as discussed above, will also increase the polysaccharidedegradation rates. Higher alkali concentrations improve 
the impregnation as this measurement is also a driving force of diffusion. Due to the Donnan effect, the ion concentration differs between the liquid penetrating the wood and that of the bulk liquid outside the chips. The concentration of $\mathrm{OH}^{-}$is lower and that of positive ions (mainly $\mathrm{Na}^{+}$) is higher in the entrapped liquid (Montagna et al. 2016). A lower initial alkali concentration even fortifies the negative effects as it leads to lower alkali concentration inside the chip and to lower diffusion rates. A higher $\mathrm{OH}^{-}$concentration increases the rate of deacetylation, the main alkali-consuming reaction during kraft pulping (Zanuttini et al. 2003, 2005), which needs to be completed before the cooking temperature is reached. As already pointed out, an increased shives content is one of the results of inhomogenous alkali concentration in the chips. The deacetylation increases the ion exchange capacity of wood (Sjöström et al. 1965), which is also manifested by an improved enzymatic hydrolysis due to the higher accessibility of the polysaccharide structures to enzymes (Kong et al. 1992). The water retention ability of wood meal also increases with increasing degrees of deacetylation (Zanuttini et al. 1998). Inalbon et al. (2009) demonstrated that deacetylation contributes a lot to wood swelling. As the blocking of $\mathrm{OH}$ groups by acetyl groups via hydrogen bonds is eliminated, swelling restrictions are removed (Sumi et al. 1964). Finally, higher ionic strength reduces the Donnan effect, and thus diminishes the difference in chemical concentration between the bulk and entrapped liquor (Kuitunen et al. 2012). A higher alkali concentration in the impregnation liquor minimizes the yield of rejects (Kleinert and Marraccini 1965; Santiago et al. 2008) and contributes to a more homogeneous impregnation (Gullichsen et al. 1995).

The goal of this study is the further investigation of the effects of an improved chip impregnation with a liquor containing higher alkali concentration than usual. This approach is called high effective alkali impregnation (HAI). The screen yield, the kappa number (KN), the xylan and galactoglucomannan (GGM), and cellulose contents, the viscosity data of the HAI pulps will be in focus in this analytical program.

\section{Materials and methods}

Fresh softwood chips - supplied by SCA AB, comprised 75\% pine and $25 \%$ spruce wood - was dried at $40^{\circ} \mathrm{C}$ to a moisture content (MC) of $8 \%$, sorted to obtain a 4-6-mm chip thickness fraction. Bark and knots were removed.

Stock solution of $\mathrm{NaOH}$ was prepared by dissolving pastilles of puriss grade (VWR International AB, Radnor, PA, USA) in deionized water and stock solution of $\mathrm{Na}_{2} \mathrm{~S}$ was prepared by dissolving technical grade flakes of $\mathrm{Na}_{2} \mathrm{~S}$ Y-hydrate, $>60 \%$ purity (VWR International $\mathrm{AB}$ ). The $\mathrm{NaCl}$ for ionic strength control was of puriss grade (VWR International $\mathrm{AB}$ ). Residual alkali was determined according to SCAN-N 33:94 in duplicate for each sample. The KN of the pulps was determined according to ISO 302:2004 in duplicate for each pulp. UV absorption was measured on a UV-2550 UV-Vis spectrophotometer (Shimadzu, Kyoto, Japan) using $0.5 \mathrm{ml}$ of spent impregnation liquor diluted 400 times with an $\mathrm{NaOH}$ solution of $\mathrm{pH} 10$.

The carbohydrate composition was determined at Innventia AB (Stockholm, Sweden) according to SCAN-CM 71 by ion chromatography; the measurement uncertainty for this determination is $\pm 2 \mathrm{mg} \mathrm{g}^{-1}$ for monosaccharides at the level of 1-10 mg g-1 and $\pm 20 \%$ for monosaccharides at a level $>10 \mathrm{mg} \mathrm{g}^{-1}$. The xylan content was calculated as arabinose+xylose, the glucomannan content as galactose $+(1+1 / 3.5) \times$ mannose and the cellulose content as glucose $-1 / 3.5 \times$ mannose. Limiting pulp viscosity was analyzed according to ISO 5351:2010.

Initial impregnation studies were performed in steel autoclaves with a volume of $2.5 \mathrm{dm}^{3}$, which were loaded with $150.0 \mathrm{~g}$ (o.d.) chips. The vessels after closing were evacuated with a vacuum pump for $30 \mathrm{~min}$. Cooking liquor was prepared from the stock solutions of $\mathrm{NaOH}$ and $\mathrm{Na}_{2} \mathrm{~S}$ to obtain $[\mathrm{HS}]=0.26 \mathrm{M}$ and $[\mathrm{OH}]=1.0 \mathrm{M}$ in the reference case (REF) and $[\mathrm{HS}]=0.26 \mathrm{M}$ and $[\mathrm{OH}]=2.0 \mathrm{M}$ in the HAI case. $\mathrm{NaCl}$ was added to the reference cooking liquor to obtain $\left[\mathrm{Na}^{+}\right]=2.3 \mathrm{M}$. The cooking liquor was then sucked into the autoclaves to obtain an $\mathrm{L} / \mathrm{W}$ ratio of $3.21 \mathrm{~kg}^{-1}$ wood.

The autoclaves were placed in a steam-heated glycol bath at $130.0^{\circ} \mathrm{C}$. Rotation and slight inclination of the autoclaves ensured good mixing. It was estimated that $10 \mathrm{~min}$ was required to heat the autoclave content to the impregnation temperature, after which the actual impregnation time started. After finishing the impregnation, the autoclaves were quenched in a water bath. The spent impregnation liquor was drained off the chips and collected for analysis. The chips were centrifuged for approx. $1 \mathrm{~min}$ to remove liquid from the chip surface as adviced by Määttänen and Tikka (2012). Then $2000 \mathrm{ml}$ of deionized water was added to the chips and the entrapped liquid was leached out for $48 \mathrm{~h}$. Residual alkali and UV absorption were determined on spent impregnation liquors and leaching liquor. Impregnation experiments were performed in duplicate.

In the cooking experiments, see Figure 1, impregnation was carried out at $130^{\circ} \mathrm{C}$ for $30 \mathrm{~min}$, at an initial effective alkali (EA) concentration of $1.0 \mathrm{M}$ in the reference case and $2.0 \mathrm{M}$ in the HAI case. After impregnation, the spent impregnation liquor was drained off resulting in a remaining $\mathrm{L} / \mathrm{W}$ ratio of $1.8 \mathrm{l} \mathrm{kg}^{-1}$ chips originally charged. Fresh white liquor was then added to the impregnated chips in order to obtain an initial EA concentration of $0.75 \mathrm{M}$ and [HS] $=0.26 \mathrm{M}$ for the reference case with an L/W ratio of $3.6 \mathrm{l} \mathrm{kg}^{-1}$ wood. The initial EA charge for the HAI cooking was $0.6 \mathrm{M}$, achieved by means of the $\mathrm{Na}_{2} \mathrm{~S}$ stock solution to obtain [HS] $=0.26 \mathrm{M}$ and deionized water to reach an $\mathrm{L} / \mathrm{W}$ ratio of $3.6 \mathrm{l} \mathrm{kg}^{-1}$. The cooking was performed in the same autoclaves used for impregnation, and the cooking temperature was $157^{\circ} \mathrm{C}$. After cooking, the black liquor was drained from the delignified chips and the residual alkali and UV absorption were measured. The chips were washed in deionized water for 10-12 $\mathrm{h}$ in self-emptying metal cylinders and then defibrated in an NAF water jet defibrator (Nordiska Armaturfabriken). The shives were collected, dried at $105^{\circ} \mathrm{C}$, and weighed. The pulp was collected, centrifuged, and dried at $105^{\circ} \mathrm{C}$; the screened yield and $\mathrm{KN}$ were determined. 

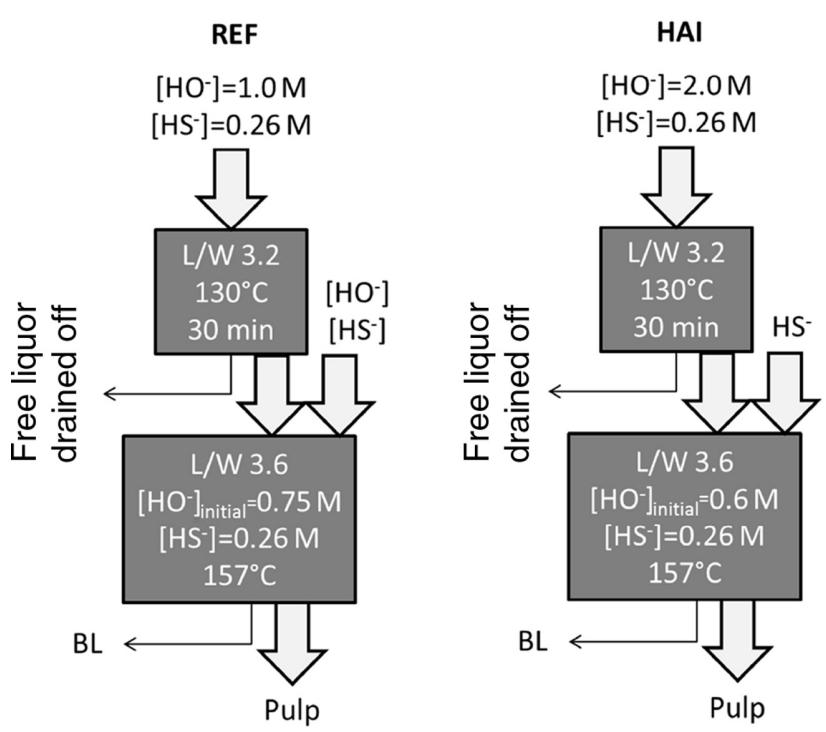

Figure 1: Flow-sheet of experimental set-up for the pulping experiments.

\section{Results and discussion}

The effect of impregnation with elevated EA concentration was studied by comparing initial EA concentrations of $1.0 \mathrm{M}$ and $2.0 \mathrm{M}$ at same $\mathrm{L} / \mathrm{W}$ ratio level. The $\mathrm{L} / \mathrm{W}$ ratio chosen is based on calculations to obtain an industrially applicable case in which an initial EA level as high as $2.0 \mathrm{M}$ could be obtained. By taking into account that fresh wood chips have a MC of approx. 50\% and white liquor from the recovery system normally has an EA concentration of $110-130 \mathrm{~g} \mathrm{l}^{-1}$, a L/W ratio of 3.2 would result in a EA concentration of $2.0 \mathrm{M}$. Figure 2a shows the alkali concentration in the liquor drained from the chips after impregnation (free liquor) and in the liquor leached from the chips (bound liquor). As can be seen, there was a rapid decrease in alkali concentration in the free liquor, as is common in alkaline cooking (Aurell 1964; Chiang et al. 1987; Pakkanen and Alén 2013). Several reactions consume alkali, such as the deacetylation of hemicelluloses, (GGM in the case of softwoods), dissolution of extractives, and neutralization of mono- and dicarboxylic acids formed in the course of peeling reaction. The alkali consumption was higher in HAI cookings. After $30 \mathrm{~min}$, approx. $120 \mathrm{~g} \mathrm{EA} \mathrm{kg}^{-1}$ wood had been consumed vs. only $100 \mathrm{~g} \mathrm{EA} \mathrm{kg}^{-1}$ wood in the reference cooks.

The time needed to reach the same alkali concentration in the free and bound liquors was similar in both the reference and HAI cooks, i.e. 20 min. This is a shorter time than that reported in other studies, in which 30 min or longer time was needed to level out the differences in alkali concentrations between the entrapped and

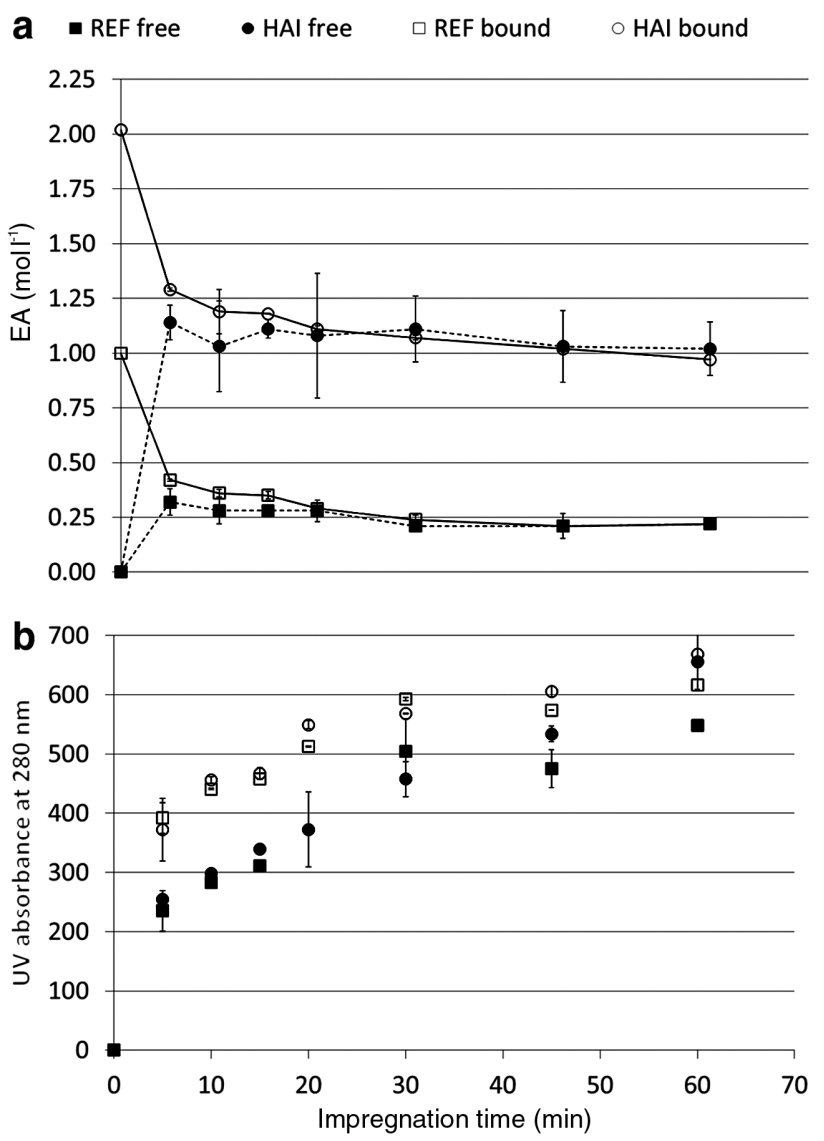

Figure 2: (a) Effective alkali (EA) concentration in the bulk liquor drained from chips after impregnation (free) and in entrapped liquor leached from chips (bound). (b) UV absorbance measured in bulk liquor drained from chips after impregnation (free) and in entrapped liquor leached from chips (bound). Error bars within $95 \%$ confidence interval.

free liquors while impregnating chips with white liquor (Määttänen and Tikka 2012). Sixty minutes was needed for impregnating chips with black liquor (Hultholm 2004).

The alkali concentration in the impregnation liquor had no effect on the amount of dissolved lignin, which was measured by UV spectroscopy at $280 \mathrm{~nm}$ (Figure $2 b)$, in either in the free liquor or the liquor entrapped in the chips. The lignin concentration was significantly higher in the latter than in the former as found already by Andersson et al. (2001). As shown in Figure 2a, the difference in alkali concentration was substantial. After 30 min of impregnation, the EA concentration was $0.25 \mathrm{M}$ in the reference case vs. $1.1 \mathrm{M}$ in the HAI case. Performing impregnation at a high EA charge resulted in rapid loading of chips with alkali. After just $5 \mathrm{~min}$, almost $90 \mathrm{~g}$ EA kg-1 wood was found in the entrapped liquor inside the chips vs. approx. $25 \mathrm{~g} \mathrm{~kg}^{-1}$ wood in the reference. The larger amount of alkali within the chips ensures that enough 
alkali is available at reaction sites at higher temperatures. However, this concentration is an average value and an alkali concentration gradient may well exist through the chips. The risk of lignin condensation reactions is therefore high in the chip core in the reference cook, especially at the final cooking temperature.

Figure 3 shows the yields after impregnation. The dissolution of wood components was rapid. After $5 \mathrm{~min}$, approx. $15 \%$ of the wood was already dissolved. Higher EA concentrations in the impregnation liquor resulted in slightly higher amounts of dissolved compounds. As the results in Figure $2 \mathrm{~b}$ indicate, the same amount of lignin was dissolved, thus it can be assumed that somewhat more xylan was dissolved in the liquor with higher EA concentration. EA concentration has been demonstrated to affect the amount of dissolved xylan (Wigell et al. 2007; Li Jansson and Brännvall 2011; Paananen et al. 2013), though Paananen et al. (2010, 2013) did not observe an effect on the total yield. A very high alkali concentration has a positive effect on the GGM yield (Paananen et al. 2010, 2013), and it can be speculated that higher GGM retention might be counteracted to some extent by increased xylan dissolution.

The yield in the present study was lower than that found in previous impregnation studies (Hultholm 2004; Määttänen and Tikka 2012). However, in those studies the impregnation temperature was lower and - as the results indicate - temperature has a decisive effect on wood dissolution, i.e. the higher the temperature, the more wood is dissolved.

In order to study the effect of HAI on pulping, chips were impregnated with an initial EA concentration of either 1.0 M (reference) or 2.0 M (HAI), and treated for $30 \mathrm{~min}$ at $130^{\circ} \mathrm{C}$, after which the spent impregnation

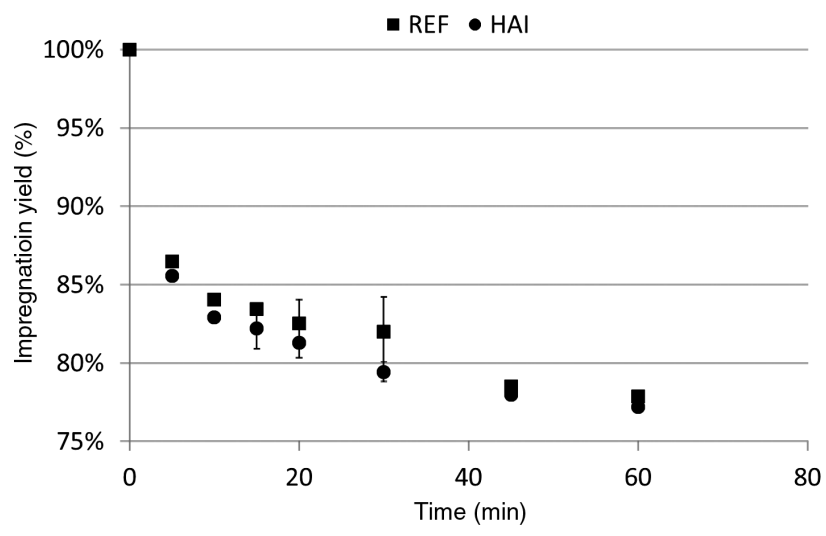

Figure 3: Yield after impregnation at $130^{\circ} \mathrm{C}$ with white liquor with initial concentration of $1.0 \mathrm{M}$ (REF) and 2.0 M (HAl).

Error bars within $95 \%$ confidence interval. liquor was drained off. Fresh white liquor was added to the chips to obtain an EA concentration of $0.75 \mathrm{M}$ (reference) and 0.60 M (HAI). The lower initial EA concentration in the latter case was chosen in an attempt to prevent excessive residual alkali levels after cooking. As indicated by the alkali profile (Figure 4a), the residual alkali was still slightly higher after a given cooking time, although the EA concentration was lower at the beginning of the cooking stage. By promoting the stopping reaction in the case of HAI, less intensive peeling of the carbohydrates can be expected and therefore smaller amounts of isosaccharinic acids will be formed. This, in turn, means that less alkali is needed for neutralizing the acids.

The alkali consumption as $\mathrm{g} \mathrm{EA} \mathrm{kg}^{-1}$ wood is presented in Table 1. During impregnation, the consumption was greater when the initial EA concentration was $2.0 \mathrm{M}$ rather than $1.0 \mathrm{M}$ (reference). During cooking to a certain KN level, however, the alkali consumption was significantly higher in the reference case, resulting in higher total alkali consumption. A relationship between alkali consumption
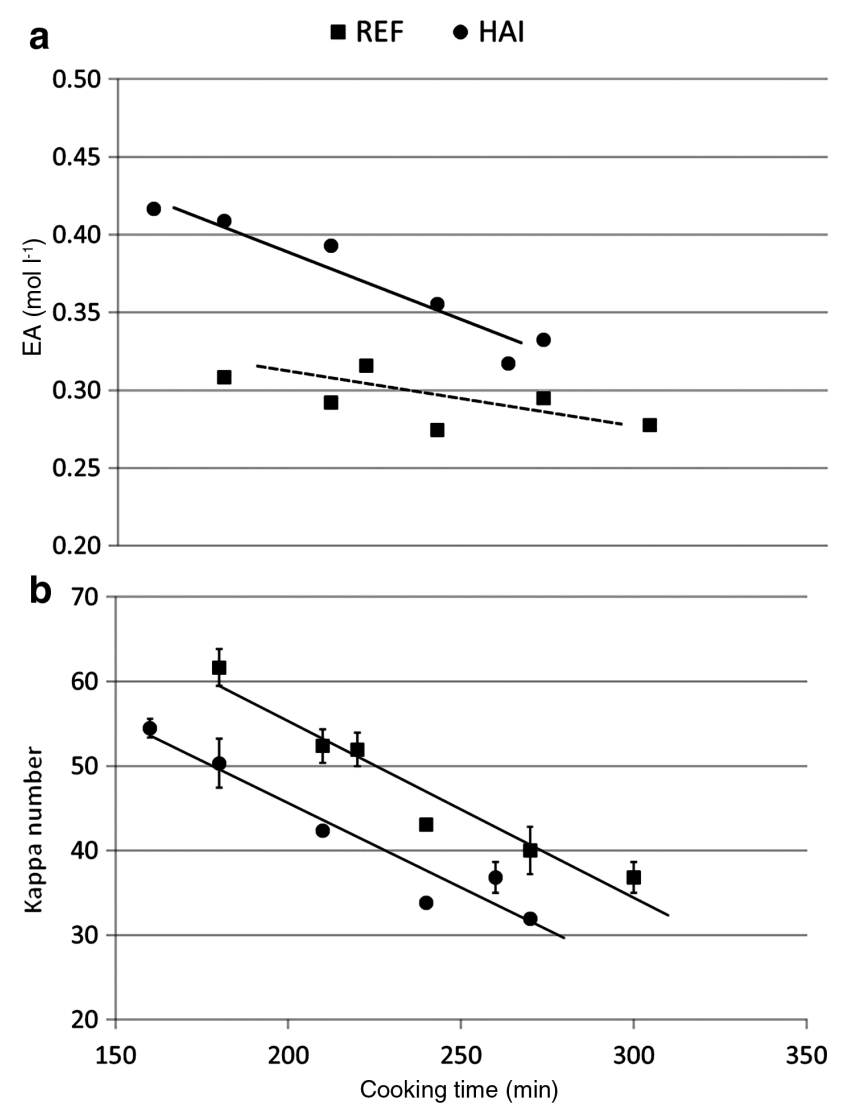

Figure 4: (a) The residual alkali in the cooking stage and (b) kappa number (KN) of pulps cooked at $157^{\circ} \mathrm{C}$ after impregnation with white liquor with initial concentration of $1.0 \mathrm{M}$ (REF) and $2.0 \mathrm{M}$ $(\mathrm{HAl})$ as a function of cooking time. Error bars within $95 \%$ confidence interval. 
Table 1: Effective alkali (EA) charge, residual alkali, and alkali consumption in impregnation and cooking stages.

\begin{tabular}{|c|c|c|c|c|c|c|c|c|}
\hline & \multirow[b]{2}{*}{ KN } & \multicolumn{3}{|c|}{ EA $\left(\mathrm{g} \mathrm{kg}^{-1}\right)$ after $30 \mathrm{~min}$ impregnation stage } & \multicolumn{3}{|c|}{ EA $\left(\mathrm{g} \mathrm{kg}^{-1}\right)$ in the cooking stage } & \multirow{2}{*}{$\begin{array}{l}\text { Total } \\
\text { consumed } \\
\text { EA }\left(\mathrm{g} \mathrm{kg}^{-1}\right)\end{array}$} \\
\hline & & Initial charge & Residual alkali & Consumed & Initial charge & Residual alkali & Consumed & \\
\hline Ref. & 43.1 & 128 & 28 & 100 & 108 & 40 & 68 & 168 \\
\hline HAI & 42.4 & 256 & 138 & 118 & 86 & 55 & 31 & 150 \\
\hline
\end{tabular}

KN, Kappa number.

in impregnation and in cooking has been demonstrated by Tolonen et al. (2010). The quoted authors found that lower alkali consumption during impregnation led to higher alkali consumption during cooking, resulting in similar total alkali consumption. However, in the quoted study the impregnation time was varied and not the alkali charge.

The cooking time for a certain degree of delignification was shorter after HAI (Figure 4b). The reference case needed approx. 45 min more time to come to the same KN level.

The yield was significantly higher at a given degree of delignification for the cooks preceded by HAI (Figure 4). As the residual alkali was higher for the HAI cooks (Figure 5), it can be assumed that more xylan redeposition occurred in the reference cooks. At KNs around 42-43, the pulping of chips impregnated with high EA had almost a $2 \%$ higher yield.

Table 2 presents the yields of chemical components (as \% based on wood), and pulps (KNs 42-43). It is evident that HAI cooking leads to a considerably higher cellulose yield. The increased yield might be attributed partly to less peeling due to the enhanced stopping reaction resulting from the elevated alkali concentration but probably more

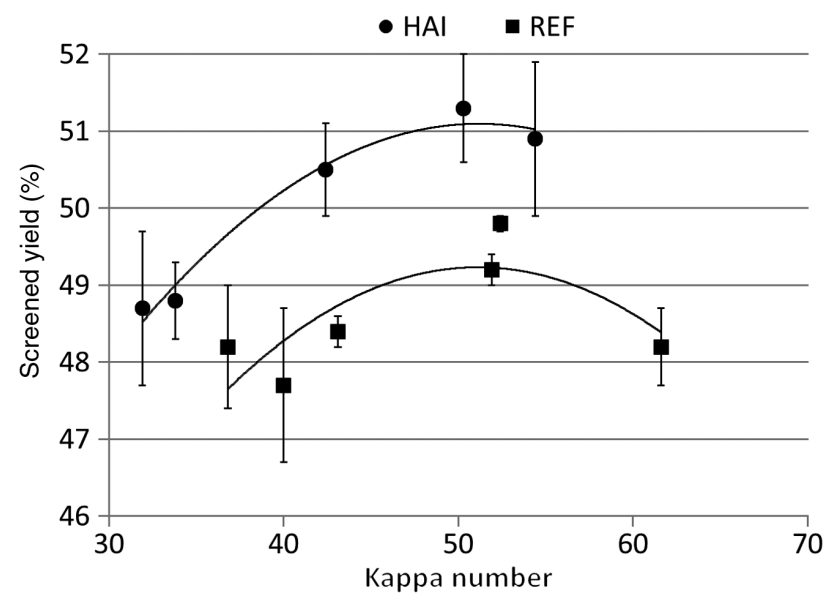

Figure 5: Screened yield of pulps cooked at $157^{\circ} \mathrm{C}$ after impregnation with white liquor with initial concentration of $1.0 \mathrm{M}$ (REF) and $2.0 \mathrm{M}(\mathrm{HAl})$.
Table 2: Yield of chemical components in wood, and pulp from reference cooking for $240 \mathrm{~min}$ (KN 43.1) and from high alkali impregnation cooking for $210 \mathrm{~min}$ (KN 42.4). Percentage data are based on dry wood.

\begin{tabular}{lrrrrrr}
\hline Sample & KN & $\begin{array}{r}\text { Yield } \\
(\%)\end{array}$ & $\begin{array}{r}\text { Xylan } \\
(\%)\end{array}$ & $\begin{array}{r}\text { GGM } \\
(\%)\end{array}$ & $\begin{array}{r}\text { Cellulose } \\
(\%)\end{array}$ & $\begin{array}{r}\text { Viscosity } \\
\left(\mathrm{ml} \mathrm{g}^{-1}\right)\end{array}$ \\
\hline Chips & - & 100 & 7.0 & 18.1 & 40.9 & - \\
Ref. 240 & 43.1 & 48.4 & 4.1 & 4.3 & 36.1 & 1200 \\
HAI 210 & 42.4 & 50.5 & 3.7 & 5.0 & 37.4 & 1200 \\
\hline
\end{tabular}

GGM, Galacto-glucomannan.

For the calculations of xylan, GGM, and cellulose, see Materials and methods.

as a result of a more homogeneous impregnation, which impedes carbohydrate degradation. In case of a shorter cooking time for a certain $\mathrm{KN}$, the cooking selectivity is more favourable for the lignin dissolution and thus the relative polysaccharide content in the pulp will be higher. However, no effect on average molecular weight of cellulose was observed if measured as limiting pulp viscosity, which was $1200 \mathrm{ml} \mathrm{g}^{-1}$ for both the reference pulp and the HAI pulp.

Previous studies performed at constant EA concentrations at either $0.31 \mathrm{M}$ and $1.55 \mathrm{M}$ (Paananen et al. 2010) or $0.5 \mathrm{M}$ and $1.55 \mathrm{M}$ (Paananen et al. 2013) found an increase in the GGM content of more than $2 \%$ at the higher alkali level. However, the total yield was similar between the high and low alkali level, due to a higher amount of xylan dissolved (Paananen et al. 2013). In cooks at high alkali level (i.e. $2.0-3.3 \mathrm{M})$ and at a low temperature $\left(130^{\circ} \mathrm{C}\right)$ (conditions for the "HALT cooks") and with the addition of polysulfide, the pulp yield was $6.7 \%$ elevated relative to reference cooks with $0.92 \mathrm{M} \mathrm{EA}$ at a cooking temperature of $160^{\circ} \mathrm{C}$ (Paananen and Sixta 2015). The yield increase was mainly due to GGM but partly also due to cellulose. The interesting finding in the present study is that increased yield has been achieved by the more homogeneous delignification without additives. By a complete impregnation before the cooking stage, no delignification gradient in the chip thickness direction occurs; thus, an excessive carbohydrate loss from the exterior part of the chips can be avoided. 
An elevated alkali at the beginning of the cooking process is a breach of the well-established concept of modified kraft cooking (MKC), where leveled-out alkali profile is the main principle (Sjöblom et al. 1983a,b; Johansson et al. 1984). The strategy of MKC research in the 1980s was to prolong the kraft cook to obtain higher degrees of delignification and to lower the demand for bleaching chemicals. The main intention was to improve the selectivity and to diminish carbohydrate degradation at a given degree of delignification as measured based on the pulp viscosity at a certain KN level. However, it is noteworthy that MKC results in the same or even in lower pulp yields at a given $\mathrm{KN}$ compared with those of conventional kraft cooking, in which all the EA is charged at the beginning of the cook (Johansson et al. 1983; Sjöblom et al. 1983a,b; Bäckström and Parming-Vass 1992). The MKC also increases the shives content (Johansson et al. 1983; Bäckström and Parming-Vass 1992), but this disadvantage was accepted as an unavoidable side-effect of the advantages. Later on, the idea of extended cooking was abandoned as it was discovered that it is more favorable to terminate the cook at a higher $\mathrm{KN}$ and to continue delignification in an oxygen stage and the benefits of a constant alkali profile were no more questioned.

For the interpretation of the results it is worth to recapitulate the course of the chip impregnation with pulping liquors, which occurs first via the lumen openings and bordered pits to adjacent tracheids. From the lumen, the hydroxide ions diffuse through the relatively porous $\mathrm{S}_{3}$ layer to the $S_{2}$ layer (Wardrop and Davies 1961). Finally, the active cooking chemicals reach the highly lignified primary wall and the less porous middle lamellae (ML). Delignification of the ML is crucial for fiber separation and thus the concentration of $\mathrm{OH}^{-}$needs to be high. The $\mathrm{L} / \mathrm{W}$ is affected by the chip MC, which can vary considerably and rapidly (Pietilä et al. 2015), hence presenting a risk of the cooking liquor to be diluted and the EA concentration decreased. However, a high alkali concentration leads to GGM stabilization through an enhanced stopping reaction (Paananen et al. 2010).

The results indicate a yield increment up to $2 \%$ by application of the HAI concept. Note that the impregnation liquor was removed before the cooking stage, i.e. the xylan dissolved during impregnation was not available during the cooking. This means that without removal of this xylan moiety the pulp yield could have been even higher (Tavast et al. 2015). It has previously been demonstrated that xylan extracted early during a kraft cook and later reintroduced into the digester will result in a pulp with higher tensile strength than pulp without xylan relocation (Tavast et al. 2015). It has been proposed that the lower tensile strength of industrial pulps can be partly explained by redeposition of xylan on the fiber surface, which was previously degraded (Brännvall and Lindström 2006). The HAI approach in combination with addition of the xylan dissolved during impregnation in the last phase of kraft cooking could improve not only the pulp yield but also its quality. Of course, this hypothesis should be verified by further experiments.

\section{Conclusions}

HAI ensures a high EA concentration within chips and prevents alkali depletion before the cooking liquor reaches the final cooking temperature. The cooking time needed to reach a certain $\mathrm{KN}$ is significantly shorter with a proceeded HAI step. The yield increase is almost $2 \%$ even without the addition of the dissolved component to a later stage of cooking. The yield increase is mainly due to a higher cellulose and GGM content of the HAI pulps, as no delignification gradient in the chip thickness direction occurs owing to a complete impregnation before the cooking stage, thus avoiding an excessive carbohydrate loss from the exterior part of the chips.

Acknowledgments: We thank Gonzalo Soler for the skilful experimental work and analysis on the pulp and liquor samples. We also thank Sharon Berkowicz for the wellperformed analysis on spent liquors. Professor Lennart Salmén is acknowledged for his valuable comments on the manuscript. We extend our gratitude to The Wood and Pulping Chemistry Research Network (WPCRN) for partly funding the study.

\section{References}

Andersson, N., Wilson, D., Germgård, U., Lindström, T. (2001) Organic matter content in black liquor inside and outside chips during kraft cooking. Paperi Puu 83:538-541.

Aurell, R. (1964) Kraft pulping of birch, Part 1: The changes in composition of the wood residue during the cooking process. Sven. Papperstid. 67:43-49.

Bäckström, M., Parming-Vass, A-M. (1992) Modifierad sulfatkokning av barrved: modellberäkningar och laboratoriekok som underlag för optimering. SCAN Forsk rapport 604, October.

Brännvall, E., Lindström, M. (2006) A study on the difference in tensile strength between industrially and laboratory-cooked pulp. Nord. Pulp Paper Res. J. 21:222-226.

Chiang, V., Cho, H., Puumala, R., Eckert, R., Fuller, W. (1987) Alkali consumption during kraft pulping of Douglas fir, western hemlock, and red alder. Tappi J. 70:101-104. 
Egas, A., Simao, J., Costa, I., Francisco, S., Castro, J. (2002) Experimental methodology for heterogeneous studies in pulping of wood. Ind. Eng. Chem. Res. 41:2529-2534.

Gullichsen, J. (1999) Fiber line operations. In: Papermaking Science and Technology, Vol. 6A. Eds. Gullichsen, J., Paulapuro, H. Fapet Oy, Helsinki. p. A74.

Gullichsen, J., Kolehmainen, H., Sundqvist, H. (1992) On the nonuniformity of the kraft cook. Paperi Puu 74:486-490.

Gullichsen, J., Hyvärinen, R., Sundqvist, H. (1995) On the nonuniformity of the kraft cook. Part 2. Paperi Puu 77:331-337.

Hartler, N., Onisko, W. (1962) The interdependence of chip thickness, cooking temperature, and screening in kraft type cooking of pine. Sven. Papperstid. 65:905-910.

Hultholm, T. (2004) Impregnation behavior of the active ions in the kraft process. PhD thesis. Åbo Akademi University, Åbo, Finland.

Inalbon, M., Mocchiutti, P., Zanuttini, M. (2009) The deacetylation reaction in Eucalyptus wood: kinetics and effects on the effective diffusion. Biores. Technol. 100:2254-2258.

Janson, J., Teder, A. (1986) A contribution to the determination of pulp yield by chemical analysis: application to modified kraft cooking of pinewood. Nord. Pulp Paper Res. J. 1:43-45, 50.

Jimenez, G., McKean, W., Gustafson, R. (1990) Using a kraft pulping model to improve pulp uniformity. Tappi J. 73:173-176.

Johansson, B., Sandström, P., Teder, A. (1983) Selektivare delignifiering genom modifierad sulfatkokning: kokförsök i laboratorieskala. STFI-meddelande serie $\mathrm{C} n \mathrm{nr} 110$.

Johansson, B., Mjöberg, J., Sandström, P., Teder, A. (1984) Modified continuous kraft pulping: now a reality. Sven. Papperstid. 87:30-35.

Kangas, P., Kaijaluoto, S., Määttänen, M. (2014) Evaluation of future pulp mill concepts: reference model of modern Nordic kraft pulp mill. Nord. Pulp Paper Res. J. 29:620-634.

Karlström, K. (2009) Extended kraft cooking on softwood: effects on reject, yield, pulping uniformity and physical properties. Lic. thesis. KTH Royal Institute of Technology, Stockholm, Sweden.

Kleinert, T., Marraccini, L. (1965) Distribution of chemicals in commercial wood chips. I. Alkaline pulping studies. Tappi 48:165-170.

Kong, F., Engler, C., Soltes, E. (1992) Effect of cell-wall acetate, xylan backbone, and lignin on enzymatic hydrolysis of aspen wood. Appl. Biochem. Biotechnol. 34-35:23-35.

Kuitunen, S., Vuorinen, T., Alopaeus, V. (2012). The role of Donnan effect in kraft cooking liquor impregnation and hot water extraction of wood. Holzforschung 67:511-521.

Li Jansson, Z., Brännvall, E. (2011) Characterisation of dissolved spruce xylan in kraft cooking. Nord. Pulp Paper Res. J. 26:380-385.

Määttänen, M., Tikka, P. (2012) Determination of phenomena involved in impregnation of softwood chips, Part 2: alkali uptake, alkali consumption and impregnation yield. Nord. Pulp Paper Res. J. 27:559-567.

Määttänen, M., Tikka, P. (2008) Penetration of water and black liquor into overthick and treated wood chips. Paperi Puu 90:34-39.

Malkov, S., Tikka, P., Gustafson, R., Nuopponen, M., Vuorinen, T. (2003) Towards complete impregnation of wood chips with aqueous solutions, Part 5: improving uniformity of kraft displacement batch pulping. Paperi Puu 85:215-220.

Montagna, P., Nieminen, K., Inalbon, M., Sixta, H., Zanuttini, M. (2016) Profiles of alkali concentration and galactoglucomannan degradation in kraft impregnation of Scots pine wood: experimental observations and modeling. Holzforschung 70:1-9.

Paananen, M., Sixta, H. (2015) High-alkali low-temperature polysulfide pulping (HALT) of Scots pine. Biores. Technol. 193:97-102.

Paananen, M., Liitiä, T., Sixta, H. (2013) Further insight into carbohydrate degradation and dissolution behavior during kraft cooking under elevated alkalinity without and in the presence of anthraquinone. Ind. Eng. Chem. Res. 52:12777-12784.

Paananen, M., Tamminen, T., Nieminen, K., Sixta, H. (2010) Galactoglucomannan stabilization during the initial kraft cooking of Scots pine. Holzforschung 64:683-692.

Pakkanen, H., Alén, R. (2013) Alkali consumption of aliphatic carboxylic acids during alkaline pulping of wood and nonwood feedstocks. Holzforschung 67:643-650.

Pietilä, J., Yli-Korpela, A., Timonen, O., Ikonen, E. (2015) Monitoring and control of chip quality in chemical pulping. Nord. Pulp Paper Res. J. 30:149-159.

Santiago, A., Neto, P., Vilela, C. (2008) Impact of effective alkali and sulfide profiling on Eucalyptus globulus kraft pulping: selectivity of the impregnation phase and its effect on final pulping results. J Chem. Technol. Biotechnol. 83:242-251.

Sjöblom, K., Hartler, N., Mjöberg, J., Sjödin, L. (1983a). A new technique for pulping to low kappa numbers in batch pulping: results of mill trials. Tappi J. 66:97-102.

Sjöblom, K., Mjöberg, J., Hartler, N. (1983b). Extended delignification in kraft cooking through improved selectivity, Part 1: the effects of inorganics composition of cooking liquor. Paperi Puu 54:227-240.

Sjöström, E., Janson, J., Haglund, P., Enström, B. (1965) The acidic groups in wood and pulp as measured by ion exchange. J. Polym. Sci. Part C. 11:221-241.

Sumi, Y., Hale, R., Meyer, J., Leopold, A., Rånby, B. (1964) Accessibility of wood and wood carbohydrates measured with tritiated water. Tappi J. 47:621-624.

Tavast, D., Jansson, Z., Brännvall, E. (2015) Influence of spruce xylan characteristics on tensile strength of spruce kraft pulp. Holzforschung 69:1-7.

Tolonen, L., Hiltunen, E., Helttunen, J., Sixta, H. 2010) Effects of impregnation time on hardwood kraft pulp characteristics and paper making potential: a mill study. Tappi J. 9:21-27.

Wardrop, A., Davies, G. (1961) Morphological factors relating to the penetration of liquids into wood. Holzforschung 15:129-141.

Wedin, H., Ragnar, M., Lindström, M.E. (2010) Extended impregnation in the kraft cook: an approach to improve the overall yield in eucalypt kraft pulping. Nord. Pulp Paper Res. J. 25:7-14.

Wigell, A., Brelid, H., Theliander, H. (2007) Degradation/dissolution of softwood hemicellulose during alkaline cooking at different temperatures and alkali concentrations. Nord. Pulp Paper Res. J. 22:488-494.

Zanuttini, M., Marzocchi, V. (2000) Pattern of alkaline impregnation of poplar wood at moderate conditions. Holzforschung 54:636-639.

Zanuttini, M., Citroni, M., Martinez, M., Marzocchi, V. (1998) Chemimechanical pulping of poplar wood: alkaline wood pretreatment at low temperature. Holzforschung 52:405-409.

Zanuttini, M., Marzocchi, V., Citroni, M., Mocchiutti, P. (2003) Alkali impregnation of hardwoods, Part I: moderate treatment of poplar wood. J. Pulp Paper Sci. 29:313-317.

Zanuttini, M., Marzocchi, V., Mocchiutti, P., Inalbon, M. (2005) Deacetylation consequences in pulping processes. Holz Roh Werkst. 63:149-153. 